PROFETIKA, Jurnal Studi Islam, Vol. 19, No.1 Juni 2018: 20 - 26

\title{
MODEL PENDIDIKAN JIHAD PONDOK PESANTREN TA'MIRUL ISLAM SURAKARTA DAN PONDOK PESANTREN DARUSY SYAHADAH BOYOLALI
}

\author{
Muh Nur Rochim Maksum
}

Guru di MA Takmirul Islam Surakarta

E-Mail: muhnurrochim23@gmail.com

\begin{abstract}
The purpose of this study was to know jihad meaning of Ta'mirul Islam boarding school leader and Darusy Shahadah boarding school leader, the model and the differences and similarities of education are applied at jihad in Ta'mirul Islam Boarding School and Darusy Syahadah boarding school 2015-2016. Type of research is a field research with qualitative methods with primary and secondary data sources, that obtained from informants in Ta'mirul Islam Boarding School and Darusy Syahadah boarding school, this data collection techniques used interviews, observation and documentation. Data analysis technique used inductive method. These results indicate that: Ta'mirul Islam boarding school leader said that meaning of jihad in accordance with the theory of Yusuf Qordowi as seriusly form of doing things. Ta'mirul Islam boarding school avoids the sense of narrowing the meaning of jihad as war. Darusy Syahadah boarding school recognizes both the meaning of jihad, either in a general sense and still looks jihad with war that must be planted in deep inside a Muslim. Jihad educational model those are applied in Ta 'mirul Islam boarding school namely: Jaulah, mujahādah, education, social Jihad, economics Jihad, education organization, said the right words to despotic leaders, the devotion of one year after graduation. Darusy Syahadah applied namely: physical Jihad, passions jihad, faith jihad, social jihad, propaganda jihad, education jihad, media jihad. Similarities of jihad education model between both boarding are namely: propaganda jihad, second: passions and devils jihad, third: amar ma'rüf nahi munkar, fourth: education jihad. The difference between them are Ta'mirul Islam boarding school used of economic jihad jihad and said the right words to despotic leader, while Darusy Syahadah did not. Darusy Syahadah boarding school implemented physical education model while Ta'mirul Islam boarding school did not apply that model.
\end{abstract}

Keyword: model; education; jihad

Abstrak: Tujuan dari penelitian ini adalah untuk mengetahui makna jihad menurut Pimpinan Pondok Pesantren Ta'mirul Islam dan Pimpinan Pondok Pesantren Darusy Syahadah, model serta perbedaan dan persamaan pendidikan jihad yang diterapkan Pondok Pesantren Ta'mirul Islam dan Pondok Pesantren Darusy Syahadah 2015-2016. Jenis penelitian yang digunakan adalah penelitian lapangan dengan metode kualitatif dengan sumber data primer dan sekunder, yang diperoleh dari informan di Pondok Pesantren Ta'mirul Islam dan Darusy Syahadah, Teknik pengumpulan data ini menggunakan metode wawancara, observasi dan dokumentasi. Sedangkan teknik analisis data yang digunakan yaitu metode induktif. Hasil penelitian yaitu: Pimpinan Pondok Pesantren Ta'mirul Islam dalam memaknai jihad sesuai dengan teori Yusuf Qordowi sebagai bentuk kesungguh-sungguhan dalam melakukan sesuatu,. Pondok pesantren Ta'mirul Islam menghindari pengertian dari penyempitan makna dari jihad itu yakni jihad yang bermakna perang. Pimpinan Pondok pesantren Darusy Syahadah mengakui kedua makna jihad, baik dalam makna umum dan tetap memamdang jihad dengan perang sebagai makna yang harus tetap di tanamkan secara mendalam dalam diri seorang muslim. Model pendidikan jihad yang di terapkan pondok pesantren Ta'mirul Islam yakni: Jaulah, mujāhadah, Pendidikan, Jihad sosial, Jihad ekonomi, Pendidikan organisasi, mengatakan perkataan yang benar kepada pemimpin yang zalim, pengabdian setahun pasca kelulusan. Model pendidikan jihad Darusy Syahadah yakni: Jihad fisik, jihad hawa nafsu, jihad aqidah, jihad sosial, jihad dakwah, jihad pendidikan, jihad media. Persamaan model pendidikan jihad antara keduanya yaitu: jihad dakwah, kedua: jihad hawa nafsu dan syaitan, ketiga: jihad amar ma 'rüf nahī munkar,keempat: jihad pendidikan. Perbedaan diantara keduanya yaitu Ta'mirul Islam menggunakan model jihad ekonomi dan model jihad dengan mengatakan perkataan yang benar dihadapan penguasa yang zalim, sedangkan Darusy Syahadah tidak menggunkannya. Darusy Syahadah menerapkan model pendidikan jihad fisik sedangkan Ta'mirul Islam sendiri tidak menerapakan model tersebut.

Kata Kunci: model; pendidikan; jihad 


\section{PENDAHULUAN}

Sesungguhnya Islam tidak dapat dipisahkan dari jihad. Dalam Islam, ada tiga tahapan yang mesti dilalui umatnya untuk mencapai kemenangan, yaitu iman, hijrah, dan jihad. 1 sebagaimana Allah berfirman,

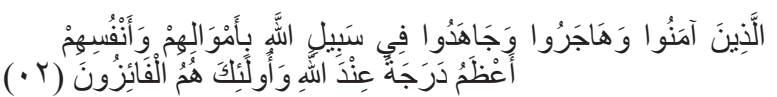

"orang-orang yang beriman dan berhijrah serta berjihad di jalan Allah dengan harta, benda dan diri mereka, adalah lebih Tinggi derajatnya di sisi Allah; dan Itulah orang-orang yang mendapat kemenangan.(QS. Al-Taubah. 20). 2

Pada akhir-akhir ini kata jihad sudah sangat melekat dengan terorisme, terutama setelah kejadian 11 September 2001,dan kejadian Bom Bali di Indonisia serta kejadia-kejadian lain yang berlabelkan jihad. 3 Al-Qur'an tidak memberikan penjelasan secara rinci tentang arti jihad. dari sekian banyak ayat yang meyebut kata jihad, tidak ada yang mendefinisikan secara lengkap apa makna jihad itu. Begitu pula dalam kitab-kitab hadits, termasuk hadits qudsi, belum ditemukan penjelasan tentang yang cukup memadai tentang pengertian tugas mulia itu. Minimnya pengertian tentang makna jihad yang bisa diyakini kebenarannya ini, menyebabkan sebagian umat Islam, dan para orang awam, kurang tepat dalam memahami jihad, apa arti dan pentingnya jihad itu. 4

Jihad menurut Majelis Ulama Indonesia, sebagaimana yang tercantum dalam keputusan fatwa majelis ulama Indonisia nomor 3 tahun 2004, jihad mengandung dua macam pengertian, yaitu: Pertama, jihad adalah segala usaha dan upaya sekuat tenaga serta kesediaan untuk menanggung kesulitan, dalam memerangi dan menahan agresi musuh dalam segala bentuknya. Jihad dalam pengertian ini juga disebut al-qitāl atau al-ḥarb. 5

Secara garis besar jenis materi pendidikan agama Islam dapat dibedakan menjadi empat jenis. Pertama, materi dasar. Di antara meteri tersebut adalah yang ada dalam ilmu tauhid (dimensi kepercayaan), fikih (dimensi perilakuritual dan sosial) akhlak (dimensi komitmen). Kedua, sekuensial. Di antara subyek yang berisi materi ini adalah Tafsir Hadis. Ketiga, instrumental. yang tergolong materi ini dalam pendidikan agama Islam, antara lain adalah bahasa Arab. Keempat, pengembang personal. Di antara materi yang termasuk dalam kategori jenis ini

1 Hilmy Bakar Almascaty, Panduan Jihad: Untuk Aktifis Gerakan Islam, (Jakarta: Gema Insani, 2001), hlm.1-2.

2 Departemen Agama RI, Al-Hidayah Al-Qur'an dan Tafsir per Kata Tajwid Kode Angka, ( Tangerang Selatan: Kalim, 2011), hlm. 190.

3 Dzulqornain M Sunisi, Antara Jihad dan Terorisme,

(Makasar, Pustaka As-Sunnah, 2011), hlm. xiii

4 Susanto Budi Wibowo, Inilah Jihad, (Yogyakarta: Gava

Media, 2012), hlm. 1.

5 Fatwa Majelis Ulama Indonisia Nomor 3 Tahun 2004, dikutip dalam buku Hilmy Bakar Almascaty, panduan..., hlm. 5. adalah sejarah kehidupan manusia, baik sejarah di masa lampau maupun kontemporer. Adapun jihad dalam pendidikan agama Islam terdapat dalam mata pelajaran fikih, konsep jihad dalam Islam merupakan materi penting bagi peserta didik. 6

Pondok Pesantren adalah salah satu lembaga pendidikan Islam, pada akhir- akhir ini Pondok Pesantren banyak disebut-sebut sebagai lembaga pendidikan Islam yang mendidik para santrinya dengan jihad yang extrem, disebabkan adanya beberapa pengajar dan alumni Pondok Pesantren yang ditangkap, karena dituduh terlibat dalam beberapa kasus terorisme yang berlabelkan jihad.

Pondok Pesantren Ta'mirul Islam didirikan oleh Naharussurur. Pada 14 Juni 1986. Sejak awal berdirinya Pondok Pesantren Ta'mirul Islam telah mendidik para santrinya dengan pendidikan jihad tidak sesempit berperang saja, melainkan ia memiliki makna yang lebih luas. 7

Pondok Pesantren Darusy Syahadah didirikan oleh yayasan Yasmin Surakarta, pada tahun 1994 di Simo, Boyolali. Darusy Syahadah adalah Pondok Pesantren yang dipandang mendidik para santrinya dengan jihad yang extrem dan condong kepada radikal. Pondok Pesantren Darusy Syahadah termasuk dalam 19 Pondok Pesantren yang dianggap radikal, yang di sampaikan melalui pernyataan kepala badan nasional penanggulangan teroris (BNPT) Saud Usman Nasution. 8

Rumusan Masalah pada penelitian ini adalah:

1) Bagaimana Pondok Pesantren Ta'mirul Islam dan Darusy Syahadah memaknai jihad dalam Islam?

2) Apa Model Pendidikan Jihad yang diterapakan Pondok Pesantren Ta'mirul Islam dan Darusy Syahadah?

3) Apa perbedaan dan persamaan Model Pendidikan Jihad yang diterapakan Pondok Pesantren Ta'mirul Islam dan Darusy Syahadah?

Tujuan Penelitian yaitu untuk mengetahui bagaimanakah Pondok Pesantren Ta'mirul Islam dan Darusy Syahadah memaknai Jihad dalam perspektif Islam, Model Pendidikan Jihad yang diterapkan di Pondok Pesantren Ta'mirul Islam dan Darusy Syahadah, perbedaan dan persamaan model Pendidikan Jihad yang diterapakan Pondok Pesantren Ta'mirul Islam dan Darusy Syahadah.

Ali Imron 2014 dalam tesisnya di STAIN Salatiga yang berjudul "Konsep Jihad dan Implementasi terhadap pembelajaran di Madrasah (Studi kasus pada Madrasah se-Kec. Karangawen, Kab. Demak Tahun 2014" , hasil penelitian ini adalah bahwa Konsep Jihad dalam Islam pandangan dari Guruguru di Madrasah Nurul Hidayah dan Madrasah Al-

\footnotetext{
6 Muhaimin, Rekonstruksi Pendidikan Islam, (Jakarta: PT RajaGrafindo Persada, 2009), hlm. 45.

7 Wawancara dengan Kafin Jaladri, pengasuh Pon-Pes Ta'mirul Islam, pada tanggal 1

12 oktober 2014.

8 http://manjanik.net/news/nasional/beredar-pesan-save pesantren-usai-bnpt-umumkan-19-ponpes-yang-dianggapradikal/. diakses pada tanggal. 19.03.2016. Jam. 13.00.
} 
Khoiriyah Karangawen Demak mempunyai banyak makna yang mencakup sejak dari sejak berjuang mengangkat senjata dalam peperangan sampai berjuang melawan hawa nafsu.

Fu'ad Riyadi 2014 dalam tesisnya di IAIN Walisongo Semarang yang berjudul

"Persepsi Jihad" ( kalangan Pondok Pesantren Al Mukmin Ngruki dan Pondok Pesantren Futuhiyah Mraggen)"

Dalam penelitian ini menjelaskan bahwa jihad yang dipersepsikan dan diaplikasikan ponpes AlMukmin adalah Jihād ta ' $I m \bar{\imath}$ dan $i$ 'dad al-quwwah( kesungguhan dalam belajar dan mempersiapkan kekuatan). Sedangkan penekanan persepsi Jihad Ponpes Futuhiyah Mranggen adalah Jihād ta'lmī dan amar ma'rūf nahī munkar (kesungguhan dalam belajar dan menyeru kapada kebaikan serta menjauhi kemungkaran).

Mohammad Fikri Pido 2011 dalam tesisnya di Universitas Gadah Mada Yogyakarta yang berjudul "Jihad Dan Kontruksi Musuh Imam Samudra", Argumentasi utama dalam tesis ini adalah Imam Samudra melihat Amerika Serikat dan demokrasi sebagai musuh dalam Jihadnya. Proses pembentukan Amerika Serikat dan demokrasi sebagai musuh sangat dipengaruhi oleh keberadaan Amerika Serikat sendiri sebagai hegemoni tunggal dan doktrin demokrasi universal dalam tatanan politik global.

\section{METODE PENELITIAN}

Penelitian ini termasuk penelitian lapangan, pendekatan penelitian yang digunakan dalam penelitian ini adalah pendekatan phenomenologis yaitu mendekati secara mendalamsuatu fenomena (peristiwa-kejadian-fakta) ayang menyita perhatian masyarakat luas karena keunikan dan kedahsyatan fenomena tersebut mempengaruhi masyarakat. 9

Obyek penelitian yang akan diteliti adalah Pondok Pesantren Ta'mirul Islam Surakarta dan Darusy Syahadah Simo Boyolali yang keduanya merupakan Pondok Pesantren yang mendidik para santri dengan berbagai macam bentuk jihad. Subyek penelitian yang akan diteliti adalah pimpinan, staf pengajar, santri dan pihak-pihak yang terlibat dalam pendidikan jihad Pondok Pesantren Ta'mirul Islam Surakarta dan Darusy Syahadah Simo Boyolali. Metode pengumpulan data yang digunakan dalam penelitian ini adalah: Metode wawancara, metode observasi dan dokumentasi.

Analisa data untuk menganalisa data yang diperoleh dari hasil penelitian, digunakan teknik dengan menelaah seluruh data, reduksi data, menyusun dalam satuan-satuan, mengategorisasi pemeriksaan keabsahan data dan yang terakhir penafsiran data.Setelah data terkumpul maka peneliti akan menarik kesimpulan yang berkaitan dengan data yang diperoleh. Dalam hal ini digunakan kerangka

9 Sudarno Shobron. dkk, Pedoman Penelitian Tesis,

(Surakarta: Sekolah Pasca Sarjana UMS Surakarta, 2015), hal. 15 berfikir induktif. 10

\section{HASIL DAN PEMBAHASAN}

Menurut Yusuf Qardawi yang dimaksud dengan jihad adalah, secara etimologi jihad isim mașdar dari kata jāhada yujāhidu-jihādan-mujāhadah, yang berarti menanggung kesulitan atau mencurahkan kemampuan. Jāhada-mujāhadah-jihādan adalah mencurahkan kemampuan untuk membela dan mengalahkan. Keterangan dalam Al-Qur'an berarti mencurahkan kemampuan untuk menyebarkan dan membela dakwah Islam. 11

Kata jihad lebih umum, mencakup seorang mujahid yang berjihad terhadap hawa nafsu, terhadap setan, amar ma'rūf nahī munkar, mengatakan perkataan yang benar dihadapan penguasa zalim dan yang lainnya. Kata jihad juga mencakup pejuang yang berperang di jalan Allah. 12

Menurut Hasan Al-Banna " yang dimaksud dengan jihad adalah sebuah kewajiban yang hukumnya tetap hingga hari kiamat. Hal ini merupakan kandungan dari apa yang disabdakan oleh Rasullullah SAW:

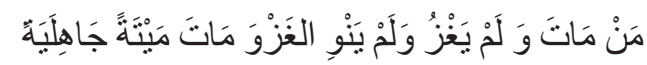

"Barangsiapa mati, sedangkan ia belum pernah berperang atau berniat untuk berperang, maka ia mati dalam keadaan jahiliyah"13

Hukum jihad menurut Yusuf Qardawi adalah wajib bagi setiap Muslim dan muslimah, baik dengan jiwanya, hartanya, lidahnya, atau hatinya, dan berjihad dengan hati adalah iman yang paling lemah.

Menurut Yusuf Qardawi yang termasuk dari jihad adalah Jihad melawan orang-orang kafir dan munafiq, berjihad terhadap hawa nafsu, terhadap setan, amar ma' rūf nahī munkar, mengatakan perkataan yang benar dihadapan penguasa zalim dan yang lainnya. Kata jihad juga mencakup pejuang yang berperang di jalan Allah.14

Menurut Hasan Al-Banna yang termasuk dari jihad fī sabīlillāh adalah:

1) Munculnya emosi yang dinamis dan kuat, yang mengaliri gelora cinta untuk meraih kembali kehormatan dan kejayaan Islam.

2) Menjadikan duka cita atas kondisi yang mengitari agama Islam sebagai pemicu dalam berpikir secara sungguh-sungguh bagaimana mendapatkan jalan keluar.

3) Menyisihkan dari sebagian waktu, sebagian harta, dan sebagian tuntutan pribadimu untuk

10 Sugiono, Metodologi Penelitian Administrasi, (Bandung: Alfabet, 2007). hal 62.

11 Yusuf Qardhawi, Fiqh Jihad, (Bandung: PT Mizan Pustaka, 2010), hlm. 3-4.

12 Ibid. 72.

13 Sa'id Hawwa, Membina Angkatan Mujahid, (Solo: Era

Intermedia, 2000), hlm.168-169.

14 Yusuf Qordowi. Fiqh..., hlm. 78-79. 
kebaikan Islam dan putra-putra kaum muslimin.

4) Memerintahkan yang ma'rūf dan mencegah yang munkar.

5) Menjadi prajurit Allah; anda melindungi-Nya dengan jiwa dan harta anda.

6) Bekerja demi menegakkan timbangan keadilan, melakukan perbaikan urusan seluruh makhluk, meluruskan tindak kezhaliman, dan mencegah tangan pelakunya seberapa pun kekuatan dan kekuasannya.

7) Memberikan cinta anda kepada para mujahid dari relung hati yang paling dalam dan memberi masukan nasehat kepada mereka dengan buah pikiran anda yang jernih. 15

Pondok Pesantren Ta'mirul Islam dalam memaknai jihad sesuai dengan teori Yusuf Qardawi sebagai bentuk kesungguh-sungguhan dalam melakukan sesuatu, sebagaimana arti bahasa dari jihad yakni berasal dari kata "jahada-yajhadu" yang bermakna besungguh-sungguh. mencakup seorang mujahid yang berjihad terhadap hawa nafsu, terhadap setan, amar ma'ruf nahi mungkar, mengatakan perkataan yang benar dihadapan penguasa zalim, dan yang lainnya. Kata jihad juga mencakup pejuang yang berperang di jalan Allah, adapun Pondok Pesantren Ta'mirul Islam menghindari pengertian dari penyempitan makna dari jihad itu yakni jihad yang bermakna perang.

Makna jihad menurut Pondok Pesantren Ta'mirul Islam juga sesuai dengan teori M Quraisy Syihab yaitu jihad bermakna sebagai usaha secara total sesuai dengan profesi dan kemampuan masingmasing individu karena Allah untuk mencapai tujuan tertentu dan tidak berhenti sebelum tujuan itu berhasil. Pondok Pesantren Ta'mirul Islam dalam memaknai makna jihad dengan membagi jihad menjadi tiga pokok makna utama, sesuai dengan profesi dan kemampuan masing masing individu sebagai dasar pendidikan jihad tersebut adapun tiga pokok makna utama jihad yaitu: 1). Jihad dengan tenaga 2). Jihad dengan Fikiran 3). Jihad dengan hati.

Jihad menurut Hasan Al-Banna dan para ulama lain yang sependapat dengan beliau, terdapat kesamaan dengan Pondok Pesantren Ta'mirul Islam yaitu dalam hal hukum wajib berjihad bagi semua manusia dalam kehidupannya, adapun Pondok Pesantren Ta'mirul Islam menghindari penyempitan makna jihad oleh Hasan Al-Banna dengan maksud berperang.

Pondok Pesantren Darusy Syahadah dalam memaknai jihad dalam makna yang umum, sesuai dengan teori Yusuf Qordowi dan M Quraish Shihab dan ulamak lain yang memaknai jihad secara luas, jihad dalam bahasa diartikan sebagai (bażlu juhdi) bersungguh-sungguh, serius dalam beragama, mengerahkan semua potensi untuk masalah agama secara maksimal, Jihad dalam makna umum dapat bermakna sebagai usaha yang sungguh-sungguh guna menegakkan dan mendakwahkan agama Allah,

15 Hasan Al-Banna, Majmungatur rosail Imam Hasan AlBanna, (Mesir: Mutobiul Wafa'). hlm. 375-377. dengan segala bentuk usahanya, yang sesuai dengan situasi dan kondisi yang terjadi.

Pondok Pesantren Darusy Syahadah dalam memaknai jihad, tidak mengesampingkan makna jihad secara khusus yang berarti perang untuk menjaga kemaslahatan manusia dan Agama. Menurut Pondok Pesantren Darusy Syahadah, apabila seseorang menafsirkan jihad hanya dengan bersungguh-sungguh saja dalam makna jihad yang umum dan tidak berarti perang maka itu termasuk berlebihan atau kurang karena dalam prakteknya perang merupakan alat dalam berjihad ketika sudah tidak ada jalan lain. Hal ini sesuai dengan pendapat Hasan Al-Banna dan ulama yang sependapat dengan beliau yang mengartikan jihad diwujudkan dengan perang dijalan Allah, serta mencela bagi mereka yang mengartikan jihad secara umum saja dan menghilangkan perang.

Perbedaan antara makna jihad perang oleh Darusy Syahdah dan Hasan Al-Banna yaitu menurut Darusy Syahadah jihad dalam arti perang dapat diwujudkan ketika dalam situasi dan kondisi tertentu seperti halnya perang melawan penjajah yang menjajah suatu negara dan sudah tidak ada jalan lain lagi untuk megusirnya. Ketika dalam suasana damai maka jihad dalam arti umumlah yang dapat diterapkan.

Pondok Pesantren Ta'mirul Islam dalam melaksanakan peran pendidikan dalam jihad berlandaskan atas kepedulian terhadap umat Islam, menyisihkan dari sebagian waktu dan sebagian harta. Melakukan perbaikan urusan seluruh makhluk serta amar ma'rūf nahī munkar. Hal ini sejalan dengan pemikiran Hasan Al-Banna dalam mengenai model jihad, yang terdiri dari jihad pendidikan, jihad dakwah melalui jaulah dan SDR (Syiar Dakah Ramadhan), jihad Sosial, pendidikan keorganisasian, mengatakan perkataan yang benar dihadapan penguasa yang zalim, pengabdian setahun pasca kelulusan dan jihad ekonomi.

Pondok Pesantren Ta'mirul Islam merancang model pendidikan jihad yang sejalan dengan pemikiran Yusuf Qardawi dalam pengimplementasian makna jihad secara umum lainya yang meliputi:1). Jihad dakwah di jalan Allah, dalam hal ini Ta'mirul Islam menggunakan model jaulah, SDR dan pengabdian setahun pasca kelulusan. 2). Jihad hawa nafsu, dalam hal ini Ta'mirul Islam mengunakan model Mujāhadah. 3). Jihad amar ma'rūf nahī munkar, dalam hal ini Ta'mirul Islam menggunakan model jihad yang meliputi: jihad pendidikan, jihad Sosial, pendidikan keorganisasian. 4). Jihad dengan mengatakan perkataan yang benar dihadapan penguasa yang zalim. 5). Jihad pendidikan, dalam hal ini Ta'mirul Islam mengajarkan kepada seluruh santri untuk dapat menguasi ilmu-ilmu agama yang di ajarkan dalam kelas maupun diluar kelas. 6). Jihad dengan harta, dalam hal ini Ta'mirul Islam mengunakan model jihad Eokonomi.

Pondok Pesantren Darusy Syahadah mendesain model-model pendidikan jihad dalam arti perang penting untuk ditanaman dalam diri santri, hal ini sesuai dengan pendapat Hasan Al-Banna. Pendidikan jihad perang disini diwujudkan bukan dalam 
persiapan perang yang sesungguhnya seperti halnya para prajurit, namun dengan model pendidikan jihad fisik yang diterapkan dalam kegiatan: beladiri, sapala, hukuman fisik yang mendidik dan sweeping. sehingga jika memang diperlukan untuk berjihad untuk turun langsung kemedan perang para santripun siap, karena sudah memiliki kemampuan dan daya tahan tubuh yang kuat.

Pondok Pesantren Darusy Syahadah sejalan dengan pemikiran Hasan Al-Banna dalam penerapan pendidikan jihad untuk para santrinya, pendidikan jihad diwujudkan dengan menumbuhkan rasa peduli dan prihatin atas keadaan umat Islam. Sejalan dengan itu maka Darusy Syahadah mendesain pendidikan jihad untuk para santrinya dengan lebih banyak untuk terjun langsung kedalam masyarakat luas, yaitu dengan model pendidikan jihad dakwah yang diwujudkan dalam pengajaran TPA, PDL (pelatihan dakwah lapangan) dan dengan kegiatan pengabdian di masyarakat selama satu tahun dan model pendidikan jihad soisal, dengan lebih peduli dengan keadaan ekonomi dan religiusitas sesama santri.

Model amar ma'rūf nahī munkar, para santri diajarkan untuk terjun langsung kelapangan dalam rangka mencegah keburukan disuatu tempat dengan kegitan sweeping, ataupun mencegah hal-hal yang tidak baik sesama santri dengan model pendidikn jihad sosial. Model tersebut sejalan dengan pemikiran Hasan Al-Banna dan Yusuf Qordowi.

Model pendidikan jihad hawa nafsu dan syaitan di Darusy Syahadah diterapkan dalam bentuk Mujāhadah yaitu dengan melaksanakan ibadahibadah wajib dan sunah, dan berdisiplin menataati seluruh disiplin pondok dan jihad aqidah dengan menanamkan aqidah yang kuat dalam diri santri sehingga terhindar dari godaan syaitan. Penerapan model tersebut sesuai dengan penerapan jihad Yusuf Qordowi.

Model pendidikan Jihad sosial di pondok Darusy Syahadah diwujudkan dengan penanaman sifat setia kawan dan membantu sesama santri. Model tersebut sejalan dengan implementasi jihad Hasan Al-Banna.

Model pendidikan jihad melalui jihad pendidikan dengan mengajarkan ilmu-ilmu agama kepada para santri serta mengajaknya unuk mengamalkannya kepada masyarakat umum maupun hanya pada teman sendiri. Hal ini sesuai dengan para ulamak yang memandang jihad secara luas. Model pendidikan jihad media, Hal ini sesuai dengan pemikiran para ulamak- ulamak kotemporer dalam penerapan jihad.

Pondok Pesantren Ta'mirul Islam dan Darusy Syahadah pada dasarnya keduanya memiliki model pendidikan jihad yang sama, yaitu model pendidikan jihad yang diterapkan dalam pengaplikasian makna jihad umum yaitu yang pertama: jihad dakwah, yang diterapkan dengan kegiatan dakwah kemasyarakat ketika bulan Ramadhan, pengabdian setahun. Adapun perbedaan diantara kedua yaitu dalam kegiatan TPA dan Jaulah. Kedua: jihad hawa nafsu dan syaitan yaitu dengan kegiatan Mujāhadah santri. Adapun Darusy Syahadah meletakkan jihad aqidah sebagai salah satu model dalam berjihad melawan syaitan. Ketiga: jihad amar ma'rūf nahī munkar. pendidikan keorganisasian atau disiplin dan jihad sosial. Adapun Darusy Syhadah menggunakan kegitan sweeping guna mencegah keburukan. Keempat: jihad pendidikan, yaitu dengan mengajarkan ilmu-ilmu agama kepada santri.

Perbedaan dalam penerapan model pendidikan jihad dari kedua Pondok Pesantren yaitu: Pertama: Ta'mirul Islam menggunakan model jihad ekonomi, sedangkan Darusy Syahadah tidak menggunakn model tersebut. Kedua: Ta'mirul Islam menggunakan model jihad dengan mengatakan perkataan yang benar dihadapan penguasa yang zalim, sedangkan Darusy Syahadah tidak menggunkannya. Ketiga: Darusy Syahadah menerapkan model pendidikan jihad fisik dalam mendidik santrinya yaitu dengan kegiatan beladiri, SAPALA, Hukuman fisik yang mendidik dan sweeping guna membentuk santri yang mempunyai daya tahan tubuh yang kuat dan kemampuan fisik, dengan tujuan kusus yaitu menjadikan santri selalu siap untuk berjihad dalam arti yang khusus apabila sesuai dengan situasi dan kondisi dan memiliki badan yang sehat pada umumnya. Ta'mirul Islam sendiri tidak menerapakan model tersebut, bahkan menghindari dari pengertian serta model pendidikan jihad yang mengarah pada perang.

\section{KESIMPULAN}

Pondok Pesantren Ta'mirul Islam memaknai jihad sebagai bentuk kesungguh-sungguhan dalam melakukan sesuatu dan menghindari pengertian dari penyempitan makna dari jihad itu yakni jihad yang bermakna perang. Adapun menurut Pondok Pesantren Ta'mirul Islam jihad dapat dilakukan dengan tenaga,. fikiran dan hati (Rūh).

Pondok Pesantren Darusy Syahadah memkanai jihad diartikan sebagai (bażlu juhdi) bersungguhsungguh. Pondok Pesantren Darusy Syahadah mengakui kedua makna jihad, baik dalam makna umum yaitu jihad dalam menegakakan Agama Allah dengan berbagai Fariannya yang sesuai dengan situasi dan kondisi zaman, dan tetap memandang jihad dengan perang sebagai makna yang harus tetap di tanamkan secara mendalam dalam diri seorang muslim.

Pendidikan jihad di Pondok Pesantren Ta $>$ mirul Islam menggunakan sistem pengajaran delapan model, yaitu:
1) Jaulah,
2) Mujāhadah,
3) Jihad Pendidikan,
4) Jihad Sosial,
5) Jihad Ekonomi,
6) Pendidikan Keorganisasian,
7) Mengatakan perkataan yang benar dihadapan pemimpin yang dzalim dan
8) pengabdian setahun pasca kelulusan. 
Pondok Pesantren Darusy Syahadah menerapkan pendidikan jihad dengan model: 1). Jihad fisik yang diterapkan dalam kegiatan: beladiri, sapala, hukuman fisik yang mendidik dan sweeping 2). Jihad hawa nafsu dan syaitan yang diterapkan dalam bentuk Mujāhadah dan berdisiplin menataati seluruh disiplin pondok yang sudah ditetapkan 3). Jihad aqidah 4). Jihad sosial, 5). Jihad dakwah yang diwujudkan dalam pengajaran TPA, PDL (pelatihan dakwah lapangan) dan dengan kegiatan pengabdian di masyarakat pasca kelulusan. 6). Jihad pendidikan 7). Jihad media.

Pondok Pesantren Ta'mirul Islam dan Darusy Syahadah pada dasarnya keduanya memiliki model pendidikan jihad yang sama, yaitu model pendidikan jihad yang diterapkan dalam pengaplikasian makna jihad umum yaitu yang pertama: jihad dakwah, yang diterapkan dengan kegiatan dakwah kemasyarakat ketika bulan Ramadhan, pengabdian setahun. Adapun perbedaan diantara kedua yaitu dalam kegiatan TPA dan Jaulah. Kedua: jihad hawa nafsu dan syaitan yaitu dengan kegiatan Mujāhadah santri. Adapun Darusy Syahadah meletakkan jihad aqidah sebagai salah satu model dalam berjihad melawan syaitan. Ketiga: jihad amar ma'rūf nahī munkar. pendidikan keorganisasian atau disiplin dan jihad sosial. Adapun Darusy Syhadah menggunakan kegitan sweeping guna mencegah keburukan. Keempat: jihad pendidikan, yaitu dengan mengajarkan ilmu-ilmu agama kepada santri.

Perbedaan dalam penerapan model pendidikan jihad dari kedua Pondok Pesantren yaitu: Pertama: Ta'mirul Islam menggunakan model jihad ekonomi, sedangkan Darusy Syahadah tidak menggunakn model tersebut. Kedua: Ta'mirul Islam menggunakan model jihad dengan mengatakan perkataan yang benar dihadapan penguasa yang zalim, sedangkan Darusy Syahadah tidak menggunkannya. Ketiga: Darusy Syahadah menerapkan model pendidikan jihad fisik dalam mendidik santrinya yaitu dengan kegiatan beladiri, SAPALA, Hukuman fisik yang mendidik dan sweeping guna membentuk santri yang mempunyai daya tahan tubuh yang kuat dan kemampuan fisik, dengan tujuan kusus yaitu menjadikan santri selalu siap untuk berjihad dalam arti yang khusus apabila sesuai dengan situasi dan kondisi dan memiliki badan yang sehat pada umumnya. Ta'mirul Islam sendiri tidak menerapakan model tersebut, bahkan menghindari dari pengertian serta model pendidikan jihad yang mengarah pada perang.

Saran-saran agar menjadi masukan bagi Model Pendidikan Jihad Pondok Pesantren Ta dan Darusy Syahadah khususnya dan pondok-Pondok Pesantren lainnya pada umumnya, antara lain:

1. Bagi kedua Pondok Pesantren diharapkan sering mengadakan evaluasi tentang model Pendidikan Jihad sehingga terus selalu terawasi model pendidikannya.

2. Harus Adanya singkronisasi jadwal kegiatan pendidikan jihad santri dengan kegiatan-kegiatan extra santri lainnya, sehingga tidak berbenturan satu sama lain.
3. Meningkatkan keistiqāmahan dalam hal kegiatan pendidikan jihad santri, yang diwujudkan dengan terjadwalnya semua kegiatan-kegiatan pendidikan jihad santri.

4. Guru/ustadz harus meningkatkan pengawasan dan bimbingan bagi santri dalam kegiatan pendidikan jihad santri sehingga tujuan dari kegiatan-kegiatan tersebut dapat dicapai secra maksimal.

5. Terkhusus bagi santri Pondok Pesantren Ta>mirul Islam agar menjadikan niat berjihad di jalan Allah sebagai niat dalam melakukan setiap kegiatan pendidikan jihad santri.

6. Menyediakan fasilitas-fasilitas yang diperlukan untuk menunjang pendidikan jihad.

7. Memenuhi semua bahan ajar yang harus disampaikan oleh santri kemasyarak haruslah disusun lebih baik, sehingga para santri mempunyai acuan dalam pelaksanaanya.

8. Selalu menanamkan jihad pada diri santri, sehingga tercipta santri yang beretos belajar dan kerja tinggi, dan penanaman bahwa jihad tidak mutlak bermakna perang.

Bagi peneliti lain yang tertarik pada fokus yang sama atau serupa, hendaknya dapat mengembangkan penelitian ini kerena pada dasarnya masih terdapat model-model pendidikan jihad yang lain yang diterapkan di lembaga pendidikan yang lain khususnya di pondok-Pondok Pesantren. 
PROFETIKA, Jurnal Studi Islam, Vol. 19, No.1 Juni 2018: 20 - 26

\section{DAFTAR PUSTAKA}

Al-Banna, Hasan. Majmungatur rosail Imam Hasan Al-Banna. Mesir: Mutobiul Wafa'.

Al-masacty, Hilmy Bakar. 2001. Panduan Jihad: Untuk Aktifis Gerakan Islam. Jakarta: Gema Insani.

Departemen Agama RI. 2011. Al-Hidayah AlQur'an dan Tafsir per Kata Tajwid Kode Angka. Tangerang Selatan: Kalim.

Hawwa, Sa’id. 2000. Membina Angkatan Mujahid. Solo: Era Intermedia.

http://manjanik.net/news/nasional/beredar-pesansave pesantren-usai-bnpt-umumkan-19ponpes-yang-dianggap-radikal/. diakses pada tanggal. 19.03.2016. Jam. 13.00.

Muhaimin. 2009. Rekonstruksi Pendidikan Islam. Jakarta: PT RajaGrafindo Persada.

Qardhawi, Yusuf. 2010. Fiqh Jihad. Bandung: PT Mizan Pustaka.

Shobron, Sudarno. Dkk. 2015. Pedoman Penelitian Tesis, Surakarta: Sekolah Pasca Sarjana UMS Surakarta.

Sugiono. 2007. Metodologi Penelitian Administrasi, Bandung: Alfabet.

Sugiono. 2007. Metodologi Penelitian Administrasi. Bandung: Alfabet.

Sunisi, Dzulqornain M. 2011. Antara Jihad dan Terorisme . Makasar: Pustaka As-Sunnah.

Wibowo, Susanto Budi. 2012. Inilah Jihad. Yogyakarta: Gava Media 